\title{
Ubehandlet syfilis - fra Oslo til Tuskegee
}

\begin{abstract}
I perioden 1891-1910 ble om lag 2000 personer med syfilis innlagt ved Rikshospitalets hudavdeling. Avdelingens leder, Cæsar Boeck (1845-1917), mente man skulle avvente sykdommens naturlige forløp og avstå fra medikamentell behandling. Han dokumenterte diagnosen og det kliniske forløpet i detalj hos alle sine pasienter. Boecks materiale er unikt og danner grunnlaget for dagens kunnskap om forløp og prognose ved syfilisinfeksjoner. Pasientene ble gransket av Boecks etterfølger ved hudavdelingen, Edvin Bruusgaard (1869-1934) i 1928 og deretter av Trygve Gjestland (1911-93). Gjestlands doktoravhandling fra 1955 er blitt stående som «Oslo-studien om ubehandlet syfilis». I denne artikkelen gir vi en vitenskapshistorisk bakgrunn for studien. Bruusgaards og Gjestlands forskning var viktig for Tuskegee-studien i USA. Oslo-studien støttet implisitt opp under dette forskningsprosjektet, som i ettertid ettertrykkelig er blitt fordømt som etisk uakseptabelt.
\end{abstract}

I 1955 avla Trygve Gjestland sin doktorgrad der han undersøkte et unikt materiale over ubehandlede syfilispasienter. Pasientene lå på Rikshospitalets hudavdeling mens Cæsar Boeck ledet avdelingen, og materialet ble først gransket av Boecks etterfølger Edvin Bruusgaard (1). Gjestlands avhandling, The Oslo study of untreated syphilis (2), er en epidemiologisk studie av 1978 pasienter med syfilis som var innlagt ved hudavdelingen i perioden 1891-1910. De fleste hadde langvarige opphold ved avdelingen, i gjennomsnitt tre måneder.

I avhandlingen gjennomgår Gjestland i detalj infeksjonens forløp og kartlegger hvor stor andel av pasientene som utviklet kardiovaskulære eller nevrologiske komplikasjoner. Det unike med denne studien er at den gir oss kunnskap om forløpet av syfilis hos pasienter som ikke fikk noen behandling. Det er fremdeles erfaringene fra denne studien vi bygger på når vi skal vurdere risikoen for komplikasjoner ved syfilisinfeksjoner.

Umiddelbart kan det virke kynisk å la være å behandle pasienter med en alvorlig infeksjonssykdom. Handlemåten kan i større grad forstås ved at vi setter oss inn i den historiske konteksten. Studiens pasienter i levde i en tid der man ikke hadde tilgang til antibiotika.

Hudavdelingen var i denne perioden ledet av Cæsar Boeck, som ble professor samme sted i 1895 . Han stilte seg skeptisk til samtidens tilgjengelige behandling i form av kvikksølvpreparater og vurderte bivirkningene av behandlingen som verre enn sykdommens skadevirkninger. Som enkelte leger på kontinentet mente han at man skulle avvente sykdommens gang, avstå fra spesifikk behandling og heller hjelpe kroppen å helbrede seg selv ved å sørge for hvile og næringsrik kost (3).

$\mathrm{Vi}$ vil i denne artikkelen gjøre rede for Oslo-studien om ubehandlet syfilis. Vi ønsker å sette den inn i en vitenskapshisto- risk sammenheng og å bidra til refleksjon over etiske aspekter ved denne viktige studien som ikke er blitt belyst tidligere.

Som bakgrunn for artikkelen har vi søkt i databaser som gir tilgang til bøker og medisinskhistorisk stoff (PubMed, History of Science, Technology \& Medicine (EBSCO), Oria) samt i vårt EndNotebibliotek. I tillegg har vi praktisert den såkalte snøballmetoden, ved at vi har fulgt relevante referanser i utvalgte artikler.

En generell oversikt over sykdommens historie finnes i ramme 1 (4-8), i ramme 2 er de forskjellige medikamentene som har vært brukt beskrevet (9-11).

\section{Bakgrunnen for Oslo-studien}

Utbredelsen av veneriske sykdommer økte kraftig i Kristiania i 1870- og 80-årene. I 1880 ble det i Norge behandlet 2848 tilfeller av syfilis, i Kristiania var det samme år 424 nye tilfeller (12). Byen var på denne tiden preget av stor tilflytting fra landsbygda. Dårlige konjunkturer gjorde at det var vanskelig for kvinner å finne arbeid. Disse faktorene kan ha bidratt til en voksende prostitusjonsvirksomhet $i$ hovedstaden.

Veneriske sykdommer, og særlig syfilis, ble betraktet som et problem som vokste i takt med økende urbanisering og industrialisering (13 s. 76). Et forsøk på å få kontroll med utbredelsen av sykdommen var påbudet om offentlig legevisitasjon av prostituerte kvinner, en praksis de fleste kjenner best gjennom Christian Krohgs bilde Albertine i politilagens ventevarelse, malt mellom 1885 og 1887. Bestemmelsen om offentlig legevisitasjon gjaldt i Norge fra 1842 til 1888 (4). En slik praksis var med på å legalisere prostitusjonen, samtidig som den ikke innebar noen form for pålegg om undersøkelse av mennene, kun kvinnene.

Det ble ansett som greit at menn hadde seksuelle erfaringer før ekteskapet - kvinnene skulle være «rene» $(14,15)$. Slik var

\author{
Anniken Sandvik \\ anniks@ous-hf.no \\ Seksjon for miljø-og arbeidsmedisin \\ Oslo Universitetssykehus, Ullevål
}

\section{Anne Kveim Lie}

Institutt for helse og samfunn

Universitetet i Oslo

\section{HOVEDBUDSKAP}

I perioden 1891-1910 ble 1978 pasienter med syfilis observert ubehandlet ved Rikshospitalets hudavdeling

Dette materialet ble undersøkt i Trygve Gjestlands doktoravhandling fra 1955 , omtalt som «Oslo-studien om ubehandlet syfilis». Som ledd i arbeidet gjennomførte Gjestland også en av de første norske undersøkelsene om sosial ulikhet i helse

Det var faglig samarbeid mellom Norge og USA i gjennomføringen av Oslo-studien og av den amerikanske Tuskegee-studien, og det ble gitt finansiell støtte fra USA til gjennomføringen av Oslo-studien 
RAMME 1

\section{Syfilis - den store imitator}

På tampen av 1400-tallet spredte en dramatisk sykdom seg raskt gjennom Europa og antok epidemiske proporsjoner. Allerede i samtiden ble det klart at den smittet ved seksuell kontakt, i ettertid har den fått navnet syfilis. Det var en aggressiv sykdom som - i motsetning til sin moderne versjon drepte i de tidlige stadier.

I dag kjenner vi syfilis som en seksuelt overførbar infeksjon forårsaket av spiroketen Treponema pallidum. Den franske venerologen Philippe Ricord (1800-89) var den første som beskrev sykdommens tre kliniske stadier, en klassifisering som man fortsatt anvender: primær-, sekundær- og tertiærfasen. Den sekundære syfilis kan, etterfulgt av en asymptomatisk latensfase, gå over i tertiær syfilis.

Latensfasen, som bare kan påvises med anamnese og serologisk undersøkelse, deles inn i tidlig latens, som er på under ett år, og sen latens, som er perioden over ett år etter smitten. Ricord mente at det bare var i det første stadiet pasientene var smittebærende, og dette var en allment akseptert oppfatning gjennom hele 1800-tallet (4 s. 219, 5 s. 142).

Sykdommen har vært omtalt som «den store imitator», da den klinisk kan arte seg på mange ulike måter. Årlig insidens på verdensbasis er i dag ca. 5,6 millioner. Syfilis er en sjelden sykdom i Norge (6).

Diagnosen mistenkes ved klinisk unders $\varnothing$ kelse og anamnese og bekreftes ved serologisk testing, en metode som først ble først beskrevet av bakteriologen August Paul von Wassermann (1866-1925) i 1906 og kalles Wassermann-reaksjonen (7). Spiroketen Treponema pallidum ble først påvist av Schaudinn og Hoffmann som det etiologiske agens for syfilis året før, i 1905 (8).

praksisen også uttrykk for ulik standard og ulik moral for kvinner og menn. Kvinnene som politilegen avdekket sykdom hos, ble innlagt i sykehus for behandling. Sannsynligvis ble mange innlagt ved hudavdelingen ved Rikshospitalet, der Cæsar Boecks forgjenger og onkel Carl Wilhelm Boeck (1808-75) praktiserte fra 1850 . Utenlandske gjester ble her vitne til tvangstiltak som låste dører på avdelingen og utvendig piggtråd (16). I en artikkel fra 1869 fordømmer den engelske legen Hutchinson (1828-1913) det at norsk

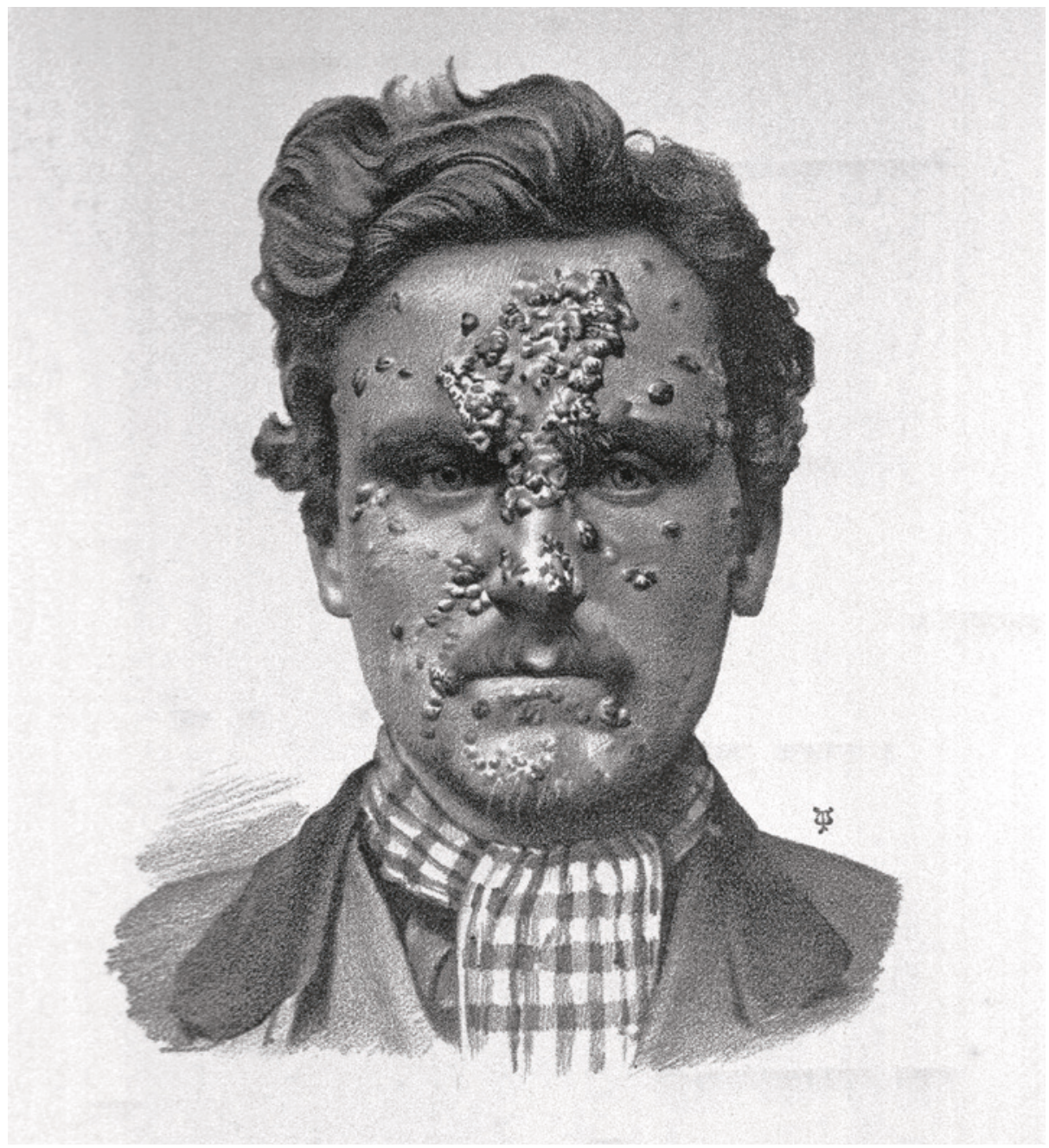

Sekundær syfilis med hudforandringer i ansiktet. Illustrasjon fra 1800-tallet. Science Photo Library

politi kunne hente personer de mistenkte hadde syfilis hjemme og sperre dem inne i månedsvis (17).

Tvangsbehandling av syfilispasienter var hjemlet i § 21 i sunnhetsloven: «Personer der lider av ondartede Sygdomme, hvis videre Udbredelse ved Smitte kan være at befrykte, skulle være forpligtede til [...] at lade sig behandle paa et Sygehuus». Begrunnelsen var, som riksadvokat Bernhard Getz (1850-1901) skrev i et lovutkast i 1892, at syfilis var «en av Menneskeslægtens frygteligste Fiender, ... en Trusel for selve Samfundene» $(18 \mathrm{~s} .9,19)$. Når en prostituert fikk konstatert en kjønnssykdom, kunne hun tvangsinnlegges (15 s. 104).

Vi vet imidlertid ikke i hvor stor utstrekning tvang faktisk ble brukt ved Rikshospitalets hudavdeling. I et materiale fra Bergen har Elisabeth Koren funnet at tvang ikke ble brukt i så stor grad, men det kunne vel være så som så med frivilligheten når man visste at tvang var riset bak speilet (19 s. 52).

I norsk målestokk var samlingen av syfilispasienter ved Rikshospitalet trolig en enestående anledning for legene til å få erfaring i å observere og behandle et relativt stort antall pasienter med samme type sykdom. Denne måten å oppnå kunnskap om en sykdom på - observere mange pasienter samlet i sykehus og gjerne sammenligne obduksjonsfunn med det man hadde observert klinisk - var en praksis som oppsto rundt år 1800. Det ble muliggjort i og med etableringen av de store allmennsykehusene med kurativ intensjon (4).

Før bakteriologiens inntog mot slutten av 1800-tallet og før utviklingen av antibiotika under den annen verdenskrig fantes det likevel etter vår målestokk få effektive midler til behandling av infeksjonssykdommer som syfilis. Rundt midten av 1800-tallet var Rikshospitalet i ferd med å bli et sted der kunnskap ble produsert ved at stadig større pasientmasser ble gjenstand for systematisk observasjon. Pasientene ble etter hvert også benyttet som objekter i utdanningen av leger (20).

Dermatologien ble etablert som egen klinisk disiplin i løpet av 1800-tallet. Tidli- 


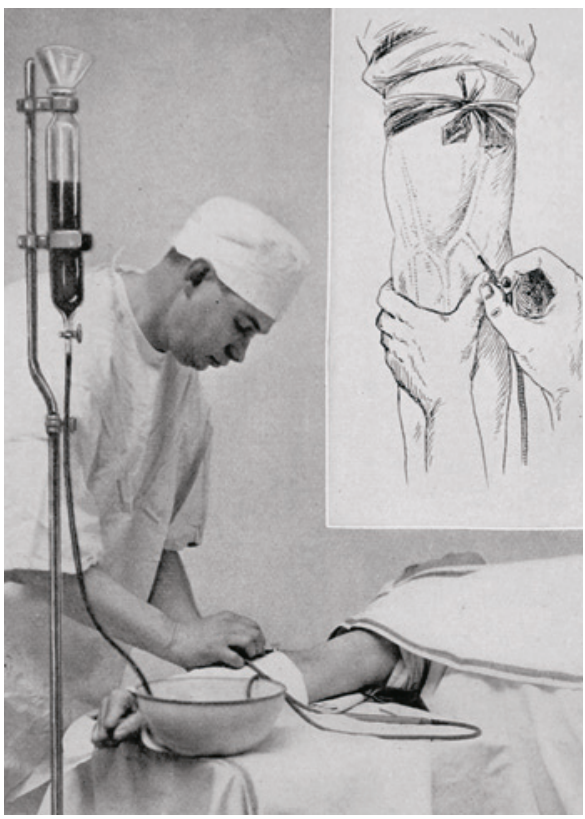

Slik skulle Salvarsan injiseres, ifølge en illustrasjon fra 1915. Fra boken Applied Immunology. The Practical Application of Sera and Bacterins Prophylactically, Diagnostically and Therapeutically, with an Appendix on Serum Treatment of Hemorrhage, Organotherapy and Chemotherapy gere var huden i hovedsak blitt oppfattet som en overflatehinne der man kunne observere kroppens indre sykdommer og som en arena for å studere kroppens naturlige helbredelsesprosess gjennom utsondringer og utslett. I løpet av første halvdel av århundret oppsto det imidlertid enighet om at huden var et organ med dybde og egen struktur.

Det ble etablert et dermatologisk klassifikasjonssystem basert på hudlesjonenes morfologi, i motsetning til tidligere beskrivelser som hadde vært basert på kroppsvæskenes tilstand, som alltid var individuelt bestemt (20). Dette muliggjorde fremveksten av en forståelse av sykdom som noe som prinsipielt sett var det samme hos alle.

Legene på denne tiden valgte gjerne én av to strategier i sin tilnærming til sykdom: enten forsøkte de relativt sterke midler for å helbrede, midler som også kunne ha alvorlige bivirkninger, eller de valgte å stole på kroppens evne til å helbrede seg selv, den «ekspektative metode» $(21,22)$.

Inspirert av franskmannen Joseph-Alexandre Auzias-Turenne (1812-70) begynte Carl Wilhelm Boeck med den såkalte syfilisasjonsmetoden. Syfilispasienter ble inoku-

\section{RAMME 2}

\section{Fra kvikksølv til penicillin}

På 1700-tallet ble kvikksølv bredt akseptert som den mest effektive medisinen mot venerisk sykdom. Samtidig ble indikasjonene for bruk av kvikksølv stadig utvidet, og kvikksølvbehandling ble også anbefalt for en rekke andre tilstander. Den humoralpatologiske begrunnelsen for bruk av kvikksølv var at pasienten gjennom økt spyttproduksjon og svette skulle bli kvitt skadelige stoffer fra kroppen. Etter hvert begynte imidlertid rapporter om kvikksølvforgiftninger å prege spaltene i de medisinske tidsskriftene. Skepsisen mot kvikksølv økte derfor utover på 1800-tallet.

Behandling med kvikksølv hadde betydelige bivirkninger, og frykten for disse kunne være vel så sterk som for følgene av sykdommen. I dag vet vi at kvikksølv kan gi skader på både det perifere og det sentrale nervesystemet.

Den utbredte bruken av kvikksølv i behandlingen av syfilis er bakgrunnen for uttrykket «a night with Venus, a lifetime with Mercury» (9).

Kvikksølv ble vanligvis administrert som kvikksølvklorid (Calomel) enten som salve (den såkalte smørekuren), dampbad, injeksjon eller i tablettform (10). Selv om både onkel og nevø Boeck var såkalte antimerkurialister og svært skeptiske til bruk av kvikksølv, fortsatte nok bruken. Bruusgaard refererer til at kvikksølv fremdeles ble brukt i norske sykehus i mellomkrigstiden (11).

I 1910 kom Salvarsan (arsfenamin) på markedet. Preparatet, også kalt komponent 606, var en organisk arsenforbindelse med toksisk effekt spesifikt rettet mot Treponema pallidum. Salvarsan var i mindre grad skadelig for kroppens øvrige celler og ga derfor mindre bivirkninger enn kvikksølv. Salvarsan ble fremstilt av legen Paul Ehrlich (1854-1915) og ble hyllet som et medisinsk gjennombrudd (8). Midlet kom raskt i utstrakt bruk, men var vanskelig og tidkrevende å administrere, og ble derfor i økende grad erstattet av Neosalvarsan.

I mellomkrigstiden ble det i noen grad brukt blandinger med sulfa og vismut. Likevel var det først da penicillinet ble tilgjengelig for allmenn bruk i 1947 at man fikk en effektiv og relativt bivirkningsfri behandling mot syfilis.

lert med puss fra sjanker hos smittede med sykdom i tidlig stadium. De fikk tallrike og gjentatte innpodninger gjennom små snitt $i$ huden over store deler av kroppen. Boecks teori var at dette ville sette i gang bedre forsvar mot sykdommen, etter samme prinsipp som Edwars Jenners koppervaksinering.

Syfilisasjonen vakte stor oppsikt internasjonalt, og i Frankrike ble Auzias-Turenne nektet å prøve ut metoden på pasienter i 1852. I Norge ble imidlertid dette utført over store deler av Østlandet. Carl Wilhelm Boeck behandlet 1075 pasienter med denne metoden (16), noe som sannsynligvis påførte de allerede stigmatiserte og svært syke menneskene ytterligere lidelse.

De negative erfaringene med syfilisasjonen kan ha vært en medvirkende årsak til at Carl Wilhelm Boecks nevø og etterfølger Cæsar Boeck valgte avventende behandling i sin avdeling. Både Carl Wilhelm og Cæsar Boeck var motstandere av kvikksølv i syfilisbehandlingen. På hver sin måte hadde de oppfatninger om at kroppen selv skulle stimuleres til motstand mot sykdommen ifølge Carl Wilhelm gjennom syfilisasjonen, ifølge Cæsar snarere ved å styrke kroppens immunforsvar ved hjelp av riktig kost og hvile inntil symptomene på infeksjonen forsvant.

I 1910 introduserte Cæsar Boeck det nyoppdagede midlet Salvarsan (arsfenamin) i behandlingen av syfilispasientene. Dette representerte et til da betydelig gjennombrudd. Med Salvarsan var perioden for observasjon av ubehandlet syfilis over.

\section{Oslo-studien}

Det omfattende journalmaterialet etter Cæsar Boeck ga en unik mulighet til å studere forløpet av ubehandlet syfilis. Boecks etterfølger ved hudavdelingen, Edvin Bruusgaard, ble den første til å analysere dette pasientmaterialet. Han utga i 1928 artikkelen Über das Schicksal der nicht spezifisch behandelten Luetiker (1). Pasientmaterialet ble etter dette kjent over hele verden som «Bruusgaard-materialet». Etter hvert viste det seg at Bruusgaards studie hadde store metodologiske svakheter, blant annet fordi det var så få av pasientene som var inkludert (kun 473) og fordi han hadde valgt ut de som var så syke at de var blitt reinnlagt (23).

Da Trygve Gjestland gjorde en fornyet studie i slutten av 1940-årene og begynnelsen av 50-årene, var det med følgende hovedproblemstilling: Hva er utfallet av syfilis i sen fase og hva er livslengde og dødsårsak hos dem som går ubehandlet med symptomatisk tidlig syfilis? Gjestland inkluderte 1404 av de opprinnelige 1978 pasientene i sin undersøkelse og gjorde grundig rede for at dette utvalget var representativt 
(24). Oslo-studien foregikk over en periode på syv år (1948-55), og omfanget av arbeidet var omfattende (23).

Cæsar Boeck observerte sine pasienter $i$ en tid før man hadde funnet frem til serologisk testing for syfilis. Det kan derfor være grunn til å diskutere hvor sikker diagnosen var. Gjestland diskuterte denne problemstillingen i sin avhandling, men konkluderte med at siden pasientene var blitt observert over såpass lang tid $\mathrm{i}$ avdelingen, var sannsynligheten for at diagnosen var korrekt ganske stor (2).

Gjestland studerte opplysninger fra pasientjournalene på Rikshospitalet og supplerte med opplysninger i folkeregisteret og øvrige registre der slike fantes. I tillegg gjorde han klinisk undersøkelse inkludert spinalpunksjon av de gjenlevende pasientene. Han gjorde et grundig arbeid i å finne frem til disse, kontaktet dem på mest mulig diskré måte og innhentet samtykke til ny undersøkelse.

Av materialet som ble studert, var det $68,2 \%$ kvinner og $31,8 \%$ menn. De fleste var unge, $88,2 \%$ tilhørte aldersgruppen 15-39 år. Av kvinnene var det flest ugifte, og de fleste anga at de arbeidet som hushjelp, industriarbeiderske eller med sying eller klesvask. Gjestland antydet at dette indikerer at de levde under dårlige sosioøkonomiske kår og at veien til prostitusjon for denne gruppen kan ha vært kort (2). Han pekte på at også mennene ser ut til å ha kommet fra underprivilegerte grupper i samfunnet, de fleste hadde adresse på Oslos østkant.

Gjestland delte studien sin inn i kapitler der han vurderte henholdsvis klinisk sekundært tilbakefall, «benign» tertiær syfilis, nevrosyfilis og kardiovaskulær syfilis. $23,6 \%$ av pasientene utviklet residiv av sekundær syfilis etter en latensperiode på opptil fem år, 15,8\% utviklet benign tertiær syfilis, 10,4\% kardiovaskulær syfilis og $6,5 \%$ nevrosyfilis (2). Disse tallene brukes fremdeles i dagens lærebøker og medisinske oppslagsverk for å angi prognosen ved syfilis.

Til slutt drøftet han «annen type sen syfilis» og vurderte hvorvidt det var økt mortalitet hos syfilispasientene sammenlignet med en kontrollgruppe. Kontrollgruppen fant Gjestland gjennom en regional studie av mortaliteten i Oslo i perioden 1891-1940 (25). Slik fikk han en kontrollgruppe fra tilsvarende sosioøkonomiske lag.

Studien representerer noe av den første

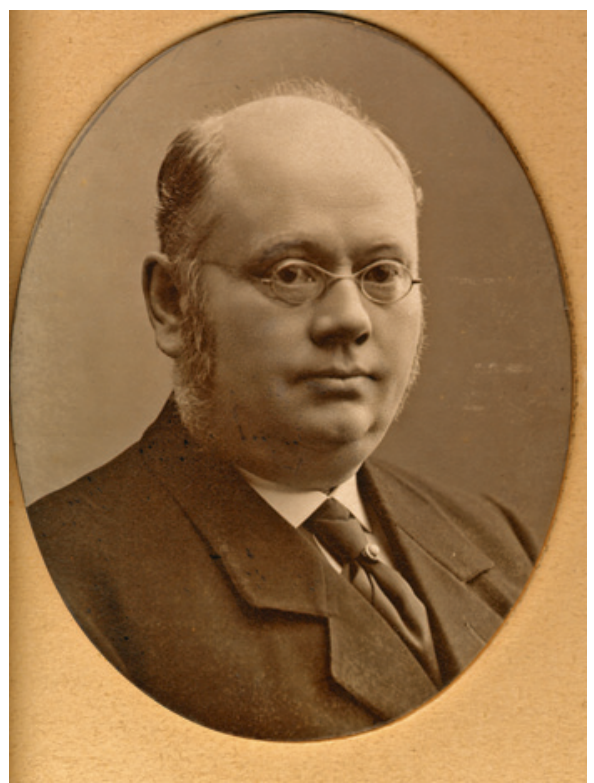

Cæsar Boeck (1845-1917). Foto: Ludvig Forbech. Publisert med tillatelse fra Universitetshistorisk fotobase

forskningen som ble gjort på sosial ulikhet i helse i Norge (26). Menn på østkanten av Oslo levde i gjennomsnitt tre år kortere

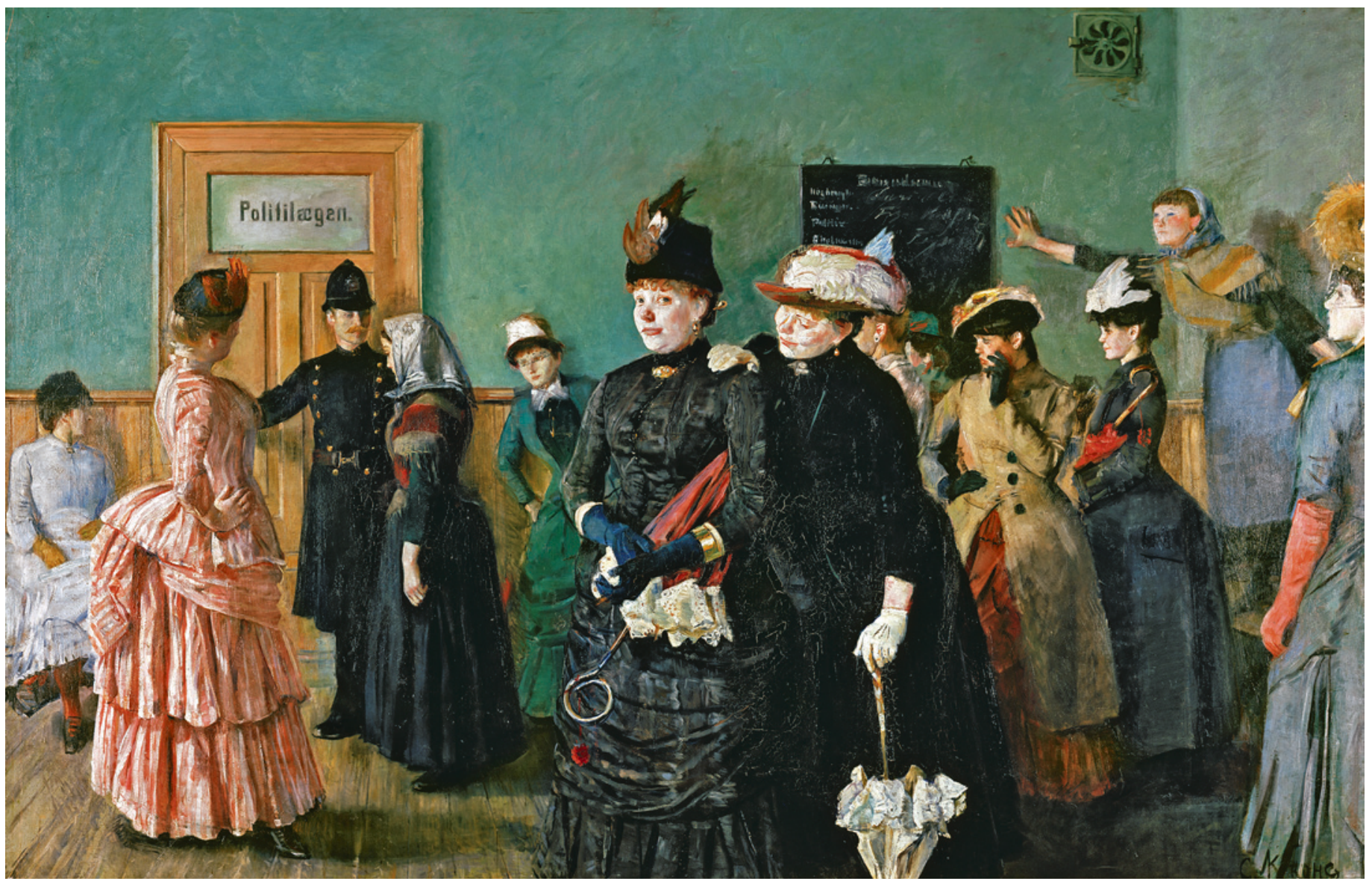

Albertine i politilægens venteværelse. Olje på lerret, malt 1885-87 av Christian Krohg (1852-1925) 




Blodprøvetaking under Tuskegee-studien. National Archives and Records Administration

enn menn på vestkanten. For kvinner var forskjellen hele fem år. Gjestland sammenlignet syfilispasientene med befolkningen på Oslos østkant og fant $53 \%$ overdødelighet for menn og $63 \%$ for kvinner (2). Han kommenterte at det både i sammenligningen mellom øst og vest generelt og i sammenligningen mellom syfilispasientene og østkantbefolkningen ble funnet at overdødeligheten hos kvinner var høyere enn overdødeligheten hos menn.

\section{I kjølvannet av Oslo-studien - Tuskegee}

I 1972 ble en stor forskningsskandale avslørt i USA. Amerikanske folkehelsemyndigheter hadde gjennomført et omfattende forskningsprosjekt om ubehandlet syfilis i byen Tuskegee i Alabama. 600 afroamerikanske menn med mistenkt syfilis ble fulgt med helseundersøkelser som blant annet inkluderte blodprøvetaking og spinalpunksjon, men uten at de på noe tidspunkt ble tilbudt behandling mot sykdommen dette til tross for at det på starttidspunktet i 1932 fantes effektiv terapi i form av Salvarsan.

Deltagelse i studien ble presentert for mennene som noe som ga økonomiske og sosiale fordeler. Ingen av deltagerne ble informert om at de hadde syfilis, tilstanden ble omtalt som «bad blood». Da penicillin ble tilgjengelig i 1947, ble ingen av Tuskegee-pasientene tilbudt denne behandlingen. Studien fortsatte helt frem til 1972, da informasjon om forskningen nådde pressen (27). I tillegg til skaden som var påført enkelt- pasienter, antas Tuskegee-studien å ha skadet afroamerikanernes tillit til statlige folkehelsekampanjer. Det har for eksempel vist seg vanskelig å få oppslutning om kampanjer mot hiv (28).

Da US Public Health Service i 1931 besluttet å sette i gang det som ble hetende Tuskegee-studien, var Bruusgaards artikkel den eneste som fantes om forløpet av ubehandlet syfilis. James Jones, som har diskutert Tuskegee-studien i detalj, skriver at «the importance of these findings for dr. Clark's proposed study of syphilis in the Negro can hardly be overstated» (28 s. 93). Særlig var det den relative hyppigheten av kardiovaskulære affeksjoner sammenlignet med nevrologiske hos pasienter med fremskreden syfilis som interesserte dem. I amerikanernes øyne rettferdiggjorde materialets svakheter en prospektiv studie, samtidig som de var interessert i å avdekke hvorvidt funnene ville bli de samme hos «the negro».

I begynnelsen av 1950-årene ble Tuskegee-studien tatt opp til ny diskusjon. Dette falt i tid sammen med Trygve Gjestlands gjennomføring av Oslo-studien. Denne studien siteres som en viktig referanse i den sammenheng (28 s. 183, 29). Gjestland mottok finansiell støtte til sin undersøkelse fra the Research Grants Division of the United States Public Health Service. Veiledere for hans avhandling var Norges daværende helsedirektør Karl Evang (1902-81) og Niels Danbolt (1900-84), overlege og professor ved Rikshospitalets hudavdeling.

I forordet til sin avhandling forteller
Gjestland også at professor Joseph Earle Moore (1892-1957) ved Johns Hopkins Hospital viste stor interesse for Bruusgaardmaterialet og at han besøkte Oslo i 1947 for å se over disse dataene. Videre skriver Gjestland at J.R. Heller (1905-89), sjef for the Veneral Disease Division of the United States Public Health Service, viste stor interesse for prosjektet og at både han og Moore øvde påvirkning for å sikre at amerikanske myndigheter bidro med økonomisk støtte til det. Både Heller og Moore var involvert i Tuskegee-studien. Den finansielle støtten til Oslo-studien ble gitt fra amerikanske myndigheter direkte til helsedirektør Karl Evang, som hadde det administrative og finansielle ansvaret for prosjektet (2).

Gjestland omtaler «the Alabama material» i kapittel 2 av sin avhandling, der han oppsummerer tidligere forskning på feltet. Han hadde et forskningsopphold ved Department of Epidemiology, School of Public Health, Columbia University i årene 1951-52 og fikk der veiledning av professor Gurney Clark (1906-74). Han møtte leger som jobbet med Tuskegee-studien og diskuterte den med dem. Han skal ha kommentert at han mente denne studien var et vitenskapelig kaos på grunn av uklar pasientkategorisering og usikre kriterier for syfilisdiagnosen.

I brev mellom forskerne fremgår det at Gjestland skal ha bemerket at man burde balansere bedre mellom undersøkelser for kardiovaskulær syfilis og nevrosyfilis slik at det i større grad ble mulig å avdekke sistnevnte tilstand (27 s. 69). Tuskegee-studiens ledere skal etter dette ha bestemt at man i større grad skulle forsøke å gjennomføre spinalpunksjoner som ledd i studien (27 s. 69).

Øvrige kilder oppgir også at det forelå et ønske om koordinering og deling av data mellom Oslo-studien og Tuskegeestudien. Gjestland oppholdt seg i Tuskegee $i$ en uke i 1951. Øyevitner til besøket hans rapporterte at han angivelig ble slått av «the remarkable socioeconomic and racial differences between the rural Alabama negro and the fair-skinned Norwegians»». Etter å ha mottatt råd fra ham bestemte de ansvarlige for Tuskegee-studien at den skulle fortsette (28 s. 183). Gjestland skrev ingenting $\mathrm{i}$ avhandlingen sin om hvorvidt de etiske sidene ved studien ble drøftet.

«The author made a visit to Alabama in 1951 and had an opportunity to discuss the various questions with the investigators then preparing the next follow-up of the patients. [...] There is little doubt that the «Alabama Study» is the best controlled experiment ever undertaken in this particular field, and the difficulties encountered 
only emphasize once more how complicated the problems are when it comes to gathering information on the prognosis of untreated syphilis» (2 s. 31).

I etterpåklokskapens lys er det nærliggende å påpeke at den norske forskergruppen ble premissleverandør til en studie det er enighet om burde ha vært avsluttet på dette tidspunktet, siden det var svært effektiv behandling tilgjengelig - i form av penicillin. Dette skjedde i en tid der oppmerksomheten rundt etiske problemstillinger i forskningen var blitt satt på dagsordenen i og med Nürnbergprosessen. Men som Henry K. Beecher skulle påpeke i en artikkel i New England Journal of Medicine i 1966 var den medisinske forskningen full av etiske overtramp. Særlig diskuterte han samtykke som problematisk i situasjoner der pasientene var avhengig av legen $\sin (30)$.

\section{Hensynet til den enkelte mot hensynet til de mange}

Oslo-studien illustrerer flere viktige aspekter ved medisinsk praksis. Den er vitenskapshistorisk viktig, ikke bare i Norge, og blir fremdeles sitert når det gjelder forløpet av ubehandlet syfilis.

Samtidig reiser den vesentlige etiske spørsmål som hittil ikke har vært tilstrekkelig belyst. Hva gjør vi som samfunn for å beskytte oss mot en sykdom det ikke finnes noen kur mot? Innesperringen av syfilispasienter i månedsvis er eksempel på at vi kan være villige til å gå langt i å innskrenke individets frihet for å beskytte samfunnet mot en smittsom sykdom. Vi bør erkjenne at politiske, kulturelle og økonomiske aspekter kan prege håndteringen av en epidemi i vel så stor grad som de rent medisinske vurderingene (31).

For øvrig er Oslo-studien et av de første eksemplene på systematisk observasjon av et sykdomsforløp under forholdsvis kontrollerte betingelser. Med Cæsar Boecks syfilispasienter ser vi et eksempel på fremveksten av både den moderne medisinske forskningsvirksomheten og av sykehusene slik vi kjenner dem i dag.

Både med Oslo-studien og Tuskegee-studien ser vi at en pasientgruppe som står lavt på samfunnets rangstige når det gjelder sykdomsart (syfilis var en stigmatisert sykdom) og sosioøkonomisk status, blir brukt for å skaffe kunnskap om en sykdom man ønsket å begrense i befolkningen som helhet. I ettertid kan vi tolke Gjestlands konsultering av Tuskegee-studiens forskere som implisitt støtte til en undersøkelse som senere er ettertrykkelig fordømt. Det var heller ikke tilfeldig at amerikanerne var så interessert i samarbeid.

Samarbeidet med USA forringer ikke

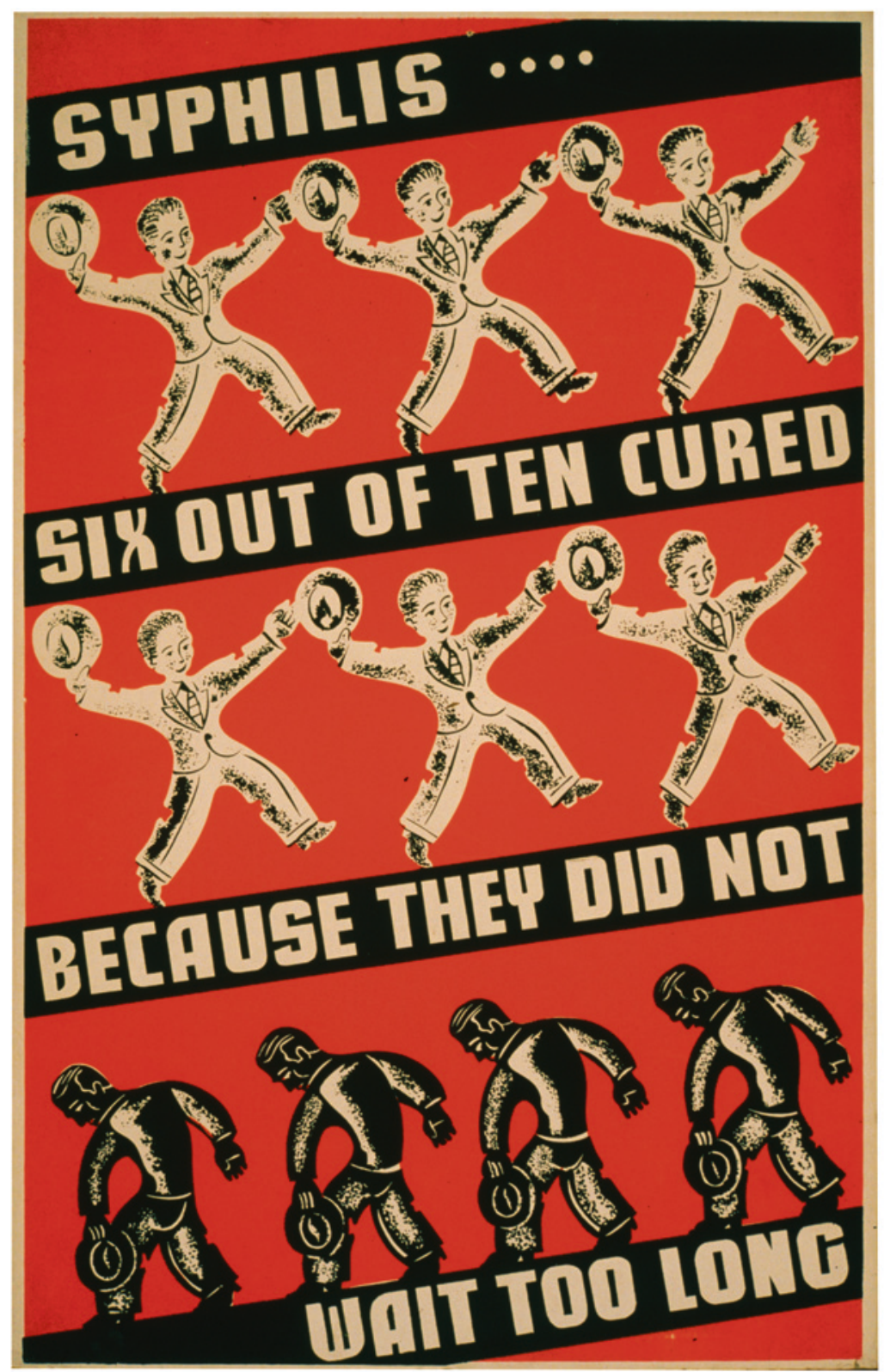

Plakat fra slutten av 1930-årene der amerikanske folkehelsemyndigheter informerer om viktigheten av tidlig behandling ved syfilis. Mary Evans Picture/NTB scanpix

den medisinske kvaliteten eller den vitenskapshistoriske relevansen av Oslo-studien. Imidlertid illustrerer dette hvor viktig det er å være ekstra oppmerksom på de etiske aspektene når det gjelder forskningssamarbeid i folkehelsespørsmål. Hvor langt kan vi strekke oss for å begrense en sykdom og for å få kunnskap om dens forløp uten å skade sårbare befolkningsgrupper? Med ebolautbruddet i Vest-Afrika nylig møtte man på viktige forskningsetiske problemstillinger av denne typen, blant annet når det gjaldt fremstilling av vaksine mot sykdommen. Hvem skulle tilbys vaksinen først, og var det etisk riktig å bruke en kontrollgruppe (32)?
Streng lovgivning på forskningsfeltet, Helsinkideklarasjonen og regionale forskningsetiske komiteer gjør det forhåpentlig lettere å unngå etiske feiltrinn. Likevel er det grunn til å huske på at en lege alltid er en del av sin samtidige historiske kontekst. Vi lager ikke regler for etiske utfordringer vi ikke selv er i stand til å identifisere. Vi bør ha et våkent blikk for hvordan våre forskningsetiske retningslinjer fungerer i praksis, ikke minst i situasjoner der viktige samfunnshensyn står på spill. 
Vi takker Jørgen Valeur, leder ved Unger-Vetlesens Institutt, Lovisenberg Diakonale Sykehus, for ideen til artikkelen og for verdifulle kommentarer underveis. Takk også for gode innspill fra tilhørere ved sisteforfatters presentasjon av materialet ved konferansen til American Association for the History of Medicine i Chicago i 2013.

\section{Anniken Sandvik (f. 1978)}

er lege i spesialisering ved Seksjon for miljøog arbeidsmedisin, Oslo universitetssykehus. Hun har en mastergrad i historie.

Forfatter har fylt ut ICMJE-skjemaet og oppgir ingen interessekonflikter.

\section{Anne Kveim Lie (f. 1969)}

er lege og førsteamanuensis i medisinsk historie ved Universitetet i Oslo.

Forfatter har fylt ut ICMJE-skjemaet og oppgir ingen interessekonflikter.

\section{Litteratur}

1. Bruusgaard E. Über das Schicksal der nicht spezifisch behandelten Luetiker. Arch Dermatol Syph 1929; 157: 309-32

2. Gjestland T. The Oslo study of untreated syphilis; an epidemiologic investigation of the natural course of the syphilitic infection based upon a re-study of the Boeck-Bruusgaard material. Acta Derm Venereol Suppl (Stockh) 1955; 35 (suppl 34): 3-368, I-LVI.

3. Hem E. Multipelt benignt hud-sarkoid - 100 år siden Caesar Boecks banebrytende artikkel. Tidsskr Nor Lægeforen 1999; 119: 4567-9.

4. Kveim Lie A. Radesykens tilblivelse: Historien om en sykdom. Oslo: Universitetet i Oslo, 2008.

5. Thyresson N. Från Fransoser till AIDS: kapitel ur de veneriska sjukdomarnas historia i Sverige. Stockholm: Carlsson, 1991.

6. Blystad H. Nettbasert veileder i smittevern for helsepersonell (Smittevernboka). www.fhi.no/ nettpub/smittevernveilederen/sykdommer-a-a/ syfilis---veileder-for-helsepersone/\#forekomsti-norge, 2015 (22.3.2016).

7. Wassermann A, Neisser A, Bruck C. A serodiagnostic reaction on syphilis. Dtsch Med Wochenschr 1906; 32: 745-6

8. Hüntelmann AC. Paul Ehrlich: Leben, Forschung Ökonomien, Netzwerke. Göttingen: Wallstein Verlag, 2011.

9. Quétel C. History of syphilis. Cambridge: Polity Press, 1990.

10. Temkin 0. Therapeutic trends and the treatment of syphilis before 1900. Bull Hist Med 1955: 29. $309-16$.

11. Bruusgaard E. Forelesninger over syfilis. Oslo: Esculap forlag, 1930

12. Beretning om Sundhetstilstanden og Medicinalforhold i Norge i 1880. Norges Officielle Statistik. Kristiania: Direktøren for det civile Medicinalvæsen, 1884.

13. Schiøtz A, Skaset M, Dimola UT. Folkets helse landets styrke 1850-2003. Oslo: Universitetsforlaget, 2003

14. Melby K. Prostitusjon og kontroll: en analyse av debatten om prostitusjon, kontroll av prostituerte kvinner og venerisk sykdom i Kristiania 1860-1900. Oslo: Universitetet i Oslo, 1977.

15. Schiøtz A. Prostitusjonen i Kristiania ca. 1870-1890: en sosialhistorisk undersøkelse. Oslo: Universitete i Oslo, 1977.

16. Fyrand O, Granholt A. The history of venereology in Norway. Genitourin Med 1994; 70: 215-7.

17. Hutchinson J. Norwegian notes. Medical Times \& Gazette 1869. https://archive.org/stream/ medicaltimesgaze39londuoft/medicaltimesgaze 39londuoft djvu.txt. (14.10.2016).

18. Getz B. Udkast til Lov til Modarbeidelse af offentlig Usædelighed og venerisk Smitte. Kristiania: Det Steenske Bogtrykkeri; 1892

19. Koren ES. «En Trusel for selve Samfundene»: venerisk sykdom: tiltak, medisinsk forståelse og moraldebatt i Norge, 1880-1927. Bergen: Univer sitetet i Bergen, 2003.

20. Lie AK. Abominable Ulcers, Open Pores, and a
New Tissue: Transforming the Skin in the Norwegian Countryside 1750-1850. I: Siena KP. Reinarz $J$, red. A medical history of skin: Scratching the

Surface. London: Pickering \& Chatto, 2013: 31-43.

21. Neuburger M. An historical survey of the concept of nature from a medical viewpoint. Isis 1944; 35 $16-28$

22. Neuburger M. Die Lehre von der Heilkraft der Natur im Wandel der Zeiten. Stuttgart: Enke, 1926.

23. Clark EG, Danbolt N. The Oslo study of the natural history of untreated syphilis; an epidemiologic investigation based on a restudy of the BoeckBruusgaard material; a review and appraisal. J Chronic Dis 1955; 2: 311-44.

24. Harrison LW. The Oslo study of untreated syphilis, review and commentary. Br J Vener Dis 1956; 32: $70-8$.

25. Gjestland T, Moen E, Trier G. En regional unders $\varnothing$ kelse av dødeligheten i Oslo 1890-1940. Første del, rapport 1954/44. Oslo: Statistisk sentralbyrå 1954.

26. Strand B, Næss $\emptyset$. Historisk helsestatistikk. Sosial ulikhet i helse 1870-2006. I: Bore R, red. På liv og død: helsestatistikk i 150 år. Oslo: Statistisk sentralbyrå, 2007.

27. Reverby SM. Examining Tuskegee: the infamous syphilis study and its legacy. Chapel Hill: University of North Carolina Press, 2009.

28. Jones JH. Bad blood: The Tuskegee Syphilis Experiment. 2. utg. New York: The Free Press, 1993.

29. MacDonald CJ. Communications: The contribution of the Tuskegee study to medical knowledge. J Natl Med Assoc 1974; 66: 1-7.

30. Beecher HK. Ethics and clinical research. N Engl Med 1966; 274: 1354-60.

31. Ryymin T. Smitte, språk og kultur: tuberkulosearbeidet i Finnmark. Oslo: Scandinavian Academic Press, 2009.

32. Grønli K. Var usikre på bruk av kontrollgruppe i Ebolaforskning. Forskningsetikk 2015 www.etikkom.no/Aktuelt/FagbladetForskningsetikk/arkiv/2015/2015-4/var-usikrepa-bruk-av-kontrollgruppe-i-ebola-forsking/ (9.6.2016).

Mottatt 20.6. 2016, første revisjon innsendt 16.10. 2016, godkjent 9.11. 2016. Redaktør: Kari Tveito. 